\title{
Corpus Pragmatics
}

\author{
Jesús Romero-Trillo
}

Published online: 18 March 2017

(C) Springer International Publishing AG 2017

The Journal Corpus Pragmatics offers a new forum for theoretical and applied linguists to publish and discuss research in this discipline that stands at the intersection of corpus linguistics and pragmatics, and I am glad that the start of the journal coincides with the 40th anniversary of the Journal of Pragmatics. In the editorial of its first issue, Haberland and Mey (1977:1) gave the following insightful definition of the, then, new discipline: "Linguistic pragmatics can, very roughly and rather broadly, be described as the science of language use." Based on this description, I would like to define Corpus Pragmatics, 'very roughly and rather broadly' too, as the science that describes language use in real contexts through corpora. In the age of the 'big data,' the journal will show that the use of corpora of different sizes and varied topics is essential to understand human communication and that corpus pragmatics provides an invaluable toolkit for linguistics due to its rigorous methodology and its multi-faceted methodological implications. In fact, we have witnessed how pragmatic research through the use of corpora has seen a steady development in the last decade, coinciding with the publication of the volume edited by Romero-Trillo (2008). Since then, many pragmaticians and corpus linguists have become aware of the enormous potential of the combination of the two disciplines, which has led to interesting and original results such as the volumes edited by, for example, Jucker et al. (2009), Romero-Trillo (2013, 2014, 2015, 2016) and Aijmer and Rühleman (2014).

Corpus Pragmatics will coexist with other academic journals that specialize in the social, cognitive, intercultural, interlanguage and philosophical angles of pragmatics. In this sense, I believe that the journal will contribute to the global development of pragmatics because it will not only concentrate on corpus pragmatics as a subject of inquiry and theoretical description in itself, but it will

Jesús Romero-Trillo

jesus.romero@uam.es

1 Departamento de Filología Inglesa, Facultad de Filosofía y Letras, Universidad Autónoma de Madrid, Madrid, Spain 
also identify methodological paths for the pragmaticians who want to provide a statistical foundation to their findings. For this reason, the aim of the journal is to participate in the development of pragmatics through empirical results and to be an agora where researchers can improve current methodologies and can apply quantitative methods to develop pragmatic theories.

Corpus Pragmatics will pay particular attention to the liaison between the delicacy of pragmatics analysis and the study of the language of new social and technological environments. Also, the comparison between ad-hoc corpora and reference corpora will be a primary objective of the journal, as in the case of interdisciplinary and under-researched topics such as the language of emotions, ideology, politics, economics, conflict, etc. In sum, I think that the Journal Corpus Pragmatics can represent a step forward in the study of language and communication and can help to develop, test and implement new and existing pragmatic theories.

\section{References}

Aijmer, K., \& Rühleman, C. (Eds.). (2014). Corpus pragmatics: A handbook. Cambridge: CUP.

Haberland, H., \& Mey, J. L. (1977). Editorial. Journal of Pragmatics, 1, 1-12.

Jucker, A., Schreier, D., \& Hundt, M. (Eds.). (2009). Corpora: Pragmatics and discourse. Amsterdam: Rodopi.

Romero-Trillo, J. (Ed.). (2008). Pragmatics and corpus linguistics: A mutualistic entente. Berlin: Mouton.

Romero-Trillo, J. (Ed.). (2013). Yearbook of corpus linguistics and pragmatics: New domains and methodologies. Dordrecht: Springer.

Romero-Trillo, J. (Ed.). (2014). Yearbook of corpus linguistics and pragmatics: New empirical and theoretical paradigms. Cham: Springer.

Romero-Trillo, J. (Ed.). (2015). Yearbook of corpus linguistics and pragmatics: Current approaches to discourse and translation studies. Cham: Springer.

Romero-Trillo, J. (Ed.). (2016). Yearbook of corpus linguistics and pragmatics: Global implications for society and education in the networked age. Cham: Springer. 